\title{
Towards a community-based concession model in the DRC
}

\author{
C. VERMEULEN ${ }^{a}$ and A. KARSENTY ${ }^{b}$ \\ ${ }^{a}$ TERRA Research Centre, Central African Forests, University of Liège - GemblouxAgro-Bio Tech, Gembloux, Belgium \\ *BIOSE, Management of Forest Resources, University of Liège - Gembloux Agro-Bio Tech, Gembloux, Belgium \\ ${ }^{b}$ French Agricultural Research Centre for International Development (CIRAD), UR GREEN, TA C-47 / F, Campus international de Baillarguet, \\ 34398 Montpellier, France
}

Email: alain.karsenty@cirad.fr, cvermeulen@ulg.ac.be

\section{SUMMARY}

In 2014 Decree 14/018 laying down the rules for granting forest concessions to local communities, followed by Ministerial Order 0/25 on the same issue, was published in the DRC. This paper aims to analyse the abovementioned legislation with respect to participatory management of forests. The explicit recognition of the duality of a customary de facto local community forest and a modern legal entity (concession) is an innovation. However, viewed from the perspective of the long-established habits within the country, the question remains whether these legal measures can be sufficient for ensuring the sustainable development of these community-held forested areas. Allowing community concessions up to 50,000 ha demonstrated a shift in the government policy away from the industrial timber cultivation model. However, an area this size is much larger than the communities can monitor, particularly in the case of artisanal charcoal or wood exploitation.

Keywords: concession, local community, community forest, decentralisation, gender

\section{Vers un modèle original de concessions communautaires en RDC}

\section{VERMEULEN et A. KARSENTY}

En 2014, le décret 14/018, suivi par l'arrêté ministériel 0/25, ont établi les règles pour l'allocation de concessions aux communautés locales. Cet article vise à analyser ce cadre réglementaire au regard de la gestion participative des forêts. La reconnaissance explicite de la dualité entre une réalité coutumière de fait - la forêt des communautés locales - et une entité légale nouvelle - la concession communautaire - constitue une innovation. Cependant, au regard des habitudes enracinées dans la gouvernance locale, on peut se demander si de telles mesures seront suffisantes pour permettre un développement durable de ces espaces communautaires. Permettre aux concessions communautaires de s'étendre jusqu'à 50.000 hectares montre une inflexion de la politique gouvernementale en défaveur de la foresterie industrielle. De telles surfaces dépassent la capacité de supervision des communautés, particulièrement pour l'exploitation artisanale du bois d'œuvre et le charbon de bois.

\section{Hacia un modelo de concesiones basado en la comunidad en la RDC}

\section{VERMEULEN y A. KARSENTY}

En 2014 se publicó en la RDC el Decreto 14/018, que establece la normativa para el otorgamiento de concesiones forestales a las comunidades locales, seguido en el mismo boletín oficial por la Orden Ministerial 0/25. El objetivo de este artículo es analizar los dos instrumentos regulatorios mencionados con respecto a la gestión participativa de los bosques. El reconocimiento explícito de la dualidad de un bosque comunitario local de facto basado en las costumbres y una entidad legal moderna (concesión) basada en prácticas consuetudinarias, es una innovación. Sin embargo, visto desde la perspectiva de las tradiciones establecidas desde antaño, la cuestión sigue siendo si estas medidas legales pueden ser suficientes. Otros factores interesantes son la demarcación participativa, la descentralización y la silvicultura social orientada hacia métodos de valoración que consumen pocos o ningún recurso, como el pago por conservación y el ecoturismo. El permitir concesiones comunitarias de hasta 50000 hectáreas ha demostrado un cambio en las políticas del gobierno, que se alejan del modelo de cultivo de madera para usos industriales. Sin embargo, un área de este tamaño es mucho mayor de lo que las comunidades pueden monitorear, en particular en el caso del carbón artesanal o la explotación de madera. 


\section{INTRODUCTION: A FORESTRY SECTOR IN TRANSFORMATION}

The forests of the Democratic Republic of the Congo (DRC) cover an area of 155 million hectares, of which 99 million hectares are rain forests. The total forested area represents $67 \%$ of the national territory. According to the State of the Forests 2010 report, the average annual rate of deforestation of the rainforests has increased from $0.15 \%$ (gross rate) during the $1990-2000$ period to $0.32 \%$ during the $2005-2010$ period. ${ }^{1}$ Recent estimates of Global Forest Watch suggest a further increase in deforestation, with nearly 2 million hectares of tree cover being lost in two years, 2013 and 2014². The leading causes of deforestation are small-scale (peasant) farming and the gathering of firewood (Defourny et al. 2011, Gillet et al. in press). Industrial concessions cover approximately 12 million hectares of forest in the DRC. However, these forests are not particularly productive, as, on average, only $2-4 \mathrm{~m}^{3}$ of timber is extracted per hectare. This low production rate is ascribed mainly to the exorbitant cost of transport. The annual volume of timber produced by these industrial concession areas is approximately $300,000 \mathrm{~m}^{3}$, which is quite low given the theoretical potential and compared with that of other Central African countries. For example, the average production by industrial forestry in Cameroon is 2.2 million $\mathrm{m}^{3}$. The artisanal sector in DRC mobilises much more wood than the industrial sector does, with over one million $\mathrm{m}^{3}$ of sawn volume produced annually, corresponding to 3.4 million $\mathrm{m}^{3}$ roundwood equivalent (RWE) (Lescuyer et al. 2014). The total production and consumption of wood is estimated 34 million $\mathrm{m}^{3}$ in RWE (Lee and Hubert 2016). A part of the industrial production and, especially, the artisanal production is exported, often illegally, to the neighbouring countries to the east of the DRC. Currently, a moratorium still prohibits any new forest industrial concessions being granted in the DRC until some key policy measures regarding the allocation of concessions are adopted (Debroux et al. 2007) $)^{3}$.

\section{CREATING OPPORTUNITIES FOR COMMUNITY FORESTS}

The long awaited Decree 14/018 "fixant les modalités d'attribution des concessions forestières aux communautés locales" (that we can translate by "Laying down the rules for granting forest concessions to local communities") was signed in 2014. This important decree ${ }^{4}$ has ushered in a form of community-based forestry, namely, participatory forest management. More recently the decree was followed by the Ministerial Order $0 / 25$ on the same topic. Consequently, the DRC joined the other countries of the Congo Basin in recognising local communities, along with the state and the industrial operators, as active partners in forest management. This decree is considered a breakthrough, as Article 22 of the 2002 Forest Code had already established the practice of community-based forestry, but the implementing legislation had not been adopted.

The present study aims to analyse this legislation promulgated by the DRC government regarding the participatory management of forests and natural resources in the country.

\section{A CONCESSION-HOLDER MODEL FOR THE PEOPLE}

It is important to note that the term "concession" is used in the DRC Forest Code. According to article 53 of the DRC Land Law, land is the exclusive, inalienable, and imprescriptible property of the state. The Forest Code reasserts that forests are the property of the state; therefore, concessions for land or forests represent the only legal channel of access to land and resources in the DRC. Article 22 is the main innovation of the Forest Code, since it states that "A local community may, on request, obtain as forest concession, a part or the whole of the protected forests among those held under customary law" ". This Article has recognised the distinction between de facto holding and ownership. Moreover, it has paved the way for an interesting concept combining a modern category (the concession) and a customary practice (the terroir, that is the customary territory, as mentioned in Art. 1, para 17 of the Forest Code). This distinction is absent, for example, from legislation on community forests in Cameroon.

Another interesting point is that the decree has made a clear difference between a local community forest and a concession. Article 18 of the decree states, "The area of a Local Community Forest is based on the extent of traditional possession" (without a predefined upper limit), whereas the limit of a forest concession granted to a local community (one or more concession holders) is 50,000 hectares. The implications of this much higher area limit than the 5,000 hectares applicable to community forests in Cameroon will be discussed later.

The third notable point is the irrevocable nature of the community forest, once the concession has been granted. Article 15 of the decree alludes to the granting of a "perpetual" forest

\footnotetext{
${ }^{1}$ If we consider the net annual deforestation rate (by taking into account planting and natural regeneration), these figures drop to 0.11 and $0.22 \%$, respectively.

2 See http://www.globalforestwatch.org/

3 In January 2016 the newly appointed minister announced his intention to begin allocating concessions again as soon as possible in order to generate more forestry revenues.

4 Available particularly at http://cd.chm-cbd.net/implementation/gestion-foresiere/decret-concessions-forestieres-communautes-locales-1-.pdf

5 French original text: 'Une communauté locale peut, à sa demande, obtenir à titre de concession forestière une partie ou la totalité des forêts protégées parmi les forêts régulièrement possédées en vertu de la coutume'
} 
concession to the local community, which means no predetermined period to request a renewal has been determined. Community concessions are therefore likely to be formally irrevocable, even if the authorisation to harvest timber and other resources might not be granted or renewed because the management rules in compliance with the regulations were not being observed. Such potential irrevocability would be a de facto recognition of strong collective property rights to lands used, in spite of the current affirmation in the Forest Code that forests belong to the state.

\section{THE IMPORTANCE OF COMMUNITY, KINSHIP AND CUSTOM}

According to Article 2 of the decree, a local community is defined as "a population traditionally organised on the basis of custom and united by bonds of solidarity in a clan or a kin, underpinning its internal cohesion. It is further characterised by its attachment to a particular land". The triad of the community, the links of kinship, and the land represents strong guarantees that, in theory, should permit only the local populations, in the strict sense of the term, to apply for a concession. This implies that any NGO, administration, or association that represents only a part of the community is excluded. However, Lescuyer et al. (2015) noted that the forestry ministry would like to see also concessions promoted by decentralised territorial entities, an option theoretically not allowed by the forest law. It is also worth noting that the law does not mention the administrative village in its definitions of "a community". In this respect, the DRC is different from Cameroon or Gabon that base the community forest request only on the resident entity recognised by the state, knowingly ignoring the clan or lineage dimension. An original feature of the DRC, which describes challenges associated with some of its innovations, is that the links of clan or kinship often extend far beyond the strict confines of the village. Consequently, numerous beneficiaries from several places of residence could emerge for a given land area, as was highlighted by Vundu dia Massamba and Kalambay Lumpungu (2013). The place of traditional leaders in this model is also well portrayed. The decree seeks to prevent a "capture by the elites" by stating "The forest concession of the local community shall remain an indivisible asset of the local community as a whole, [the forest] does not belong to any association or to any corporation, let alone to the representative(s) of the community [...]". The ministerial order confirms that the community assembly shall be the governing body of the concession. The intent of the legislation could not be clearer. However, taking into account the power and standing of the traditional leaders in the DRC, this intention could become undermined in practice by culture and the power of these community leaders.

The decree and order confirm some traditional powers, which is a noticeable development in relation to other legislation on community forestry in the sub-region. This strong traditional character has advantages but there are also concerns, for instance, about the presence and voice of migrant populations. Migrants are present in numerous villages in the
DRC and their numbers sometimes exceed those of the original landowners. Although these migrants have often lived in the villages for decades, they are not entitled to the traditional rights to lands and resources. The question, therefore, is what would happen if these migrant populations, who are consumers of resources on a par with the traditional rights holders, were to be excluded from the concession-related management processes and profit-sharing merely because of custom. Analyses pertaining to space resource management have indicated that such exclusion often leads to predatory behaviour, especially as regards migrant populations (see, in particular, Laurent and Mathieu 1994).

\section{THE GENDER ISSUE}

Gender is another concern in relation to the emphasis on tradition. Although the leaders of the clans and lineages or the public figures in these patriarchal societies are mostly men, women represent significant percentage of the users of the forest ecosystem. The problem is how to ensure that their opinions and interests are given due consideration in such an environment. The Cameroonian legislation pertaining to community forestry does not mention traditional structures and a priori grants women a more prominent role. It has been shown (Tobith and Cuny 2006) that women in Cameroon are involved at the initial stages, such as meetings and the preparation of simple forest management plans. However, women are not sufficiently represented during the decision-making phases, such as the constitution of the legal entity, allocation of the forest, or the submission of dossiers to the administration. Moreover, the management and benefits-sharing process often exclude women (Bouki 2016). It is feared, therefore, that the model based on traditions and cultural entities (clans, lineages, families, and the like) proposed for the DRC would largely marginalise women. The provisions of Ministerial Order 025 on the participation of "all groups" in the community assembly or in the management committee are not sufficient to overcome the gender issue.

\section{RECOGNISING DUAL PRACTICE-A SIGNIFIANT STEP}

In contrast with the legislation of Cameroon or Gabon, which overlooks the dual dimension of community forestry, the DRC Decree no. 14/018 specifically recognises community forestry and its dual character.

The decree differentiates between:

- A customary practice ('local community forests', equivalent to landholding) which corresponds to a de facto relationship and does not require institutionalisation, but could benefit from policy recognition, converted into management principles, by participatory mapping;

- An institutional innovation (community concession) that derives from a customary practice but is distinct from it. 
'Local community forests' can extend over large areas, do not necessarily have precisely defined boundaries, could comprise (depending on the use of the resources specific to different communities) a scattered network of trails and places of activity, and constitute a space that can overlap — or be superimposed on - legal categories, such as industrial concessions or protected areas. Since local community forests are a matter of fact, there is no reason to confine or restrict their area by a regulatory instrument. As a customary practice, these forests should continue to be governed by the traditions prevailing in the relevant communities, and the regulations should therefore not impose a governance structure on them. Participatory mapping could facilitate the obtainment of social and political recognition for the practice of community forestry. The resulting maps could form the basis of contractual agreements (e.g., between an industrial concession holder and the community) on managing the overlaps between the customary forest and the industrial concession. In Gabon, these community forests are designated as village landholdings ${ }^{6}$ and are sometimes used for establishing an economic partnership between the farmers and the communities (money is allocated to community development by the concession holders in proportion to the overlapping of the landholding and the concession granted by the state to the operator).

The community concession is a separate entity to which communities have exclusive rights, mainly for the production of timber and other natural resources. The decree states that the "concessions will be clear of all rights". Therefore, no overlapping of industrial concessions with this category is allowed, as this category pertains to a de facto, as well as a legal relationship. Even though the category derives from customary practice, the difference is, as stipulated in the decree, that the members of its management bodies will be accountable to the whole community. Appointing the senior management by election appears to be the most suitable form to ensure accountability corresponding to the management responsibilities.

However, it has to be noted that the arbitration process set out in the legislation does not provide for a reservation process that would benefit the people, as it has been done in Gabon. The law embodies a midway policy currently in force in some Congo Basin countries, where in recent regulations there is increasing recognition of local land rights which impinge on industrial concessions, often indirectly such as in Gabon (the Order refers explicitly to customary landholdings called "finages") and Congo Brazzaville (with areas of communitarian development). But this recognition does not go as far as to prevent new concession allocations in case of local opposition, and even less to challenge the existence of the current ones. This is why policy proposals designed to recognise and manage overlapping rights on existing industrial concessions seem best adapted to the mentality and to Congo Basin policymakers' mindsets (see Karsenty and Vermeulen 2016).

\section{A PARTICIPATORY APPROACH?}

Article 4 of the decree provides for the applicant community to submit a "map prepared in a participatory manner in collaboration with neighbouring communities and other stakeholders". Whereas the presence of neighbouring communities is welcomed, guaranteeing an adversarial demarcation process, the provision does not specify the identity of these stakeholders. The interests of numerous parties should be considered during the consultative process to establish large concession areas; however, a restrictive list could also be useful. The reason for this is that the mobilisation of these actors could be costly for the local community, as has been demonstrated by the experience in Cameroon (Julve et al. 2007). It is also noteworthy that the decree does not prescribe the use of a geographic information system (GIS) or a global positioning system (GPS), a scale, or even a background map. Therefore, the communities are spared the expense of hiring consultants. In Gabon, simple management plans, using the most basic technical concepts possible and without any accurate background maps have been tested (Schippers et al. 2008). The disadvantage of this simplistic approach is that it deprives people of a strong technical base for further negotiations with the state and other partners (especially as regards the possible first-refusal for future concessions by local communities, given the presence of other players).

As regards participatory management, Ministerial Order 025 calls for the establishment of four structures: a community assembly, a management committee, a local control committee, and a council of elders. The implicit hierarchy displayed in this list seems to call for an appropriate participatory approaches and resolution of conflicts. However, it is feared, here again, that the groups generally excluded from traditional power, such as women, youth, migrants, poor people, etc. would not be empowered. Experience in the initial community forests of Gabon has shown that youth, were marginalised more often than the other groups, (Boldrini et al. 2014) and this situation could also occur in the DRC. Moreover, the proliferation of decision-making and intermediation structures (four for a community in DRC) is not a guarantee of success, as these structures can enter into competition: studies in Cameroon showed that external structures of governance imposed on local communities are a source of conflict (Ezzine De Blas et al. 2011, Bouki 2016).

\section{A DECENTRALISED PROCESS}

The decentralised character of the decree is another original feature. Unlike countries such as Gabon or Cameroon, where the allocation decision is vested in a centralised supervisory authority and has to be signed by the minister of forests, the DRC process is devolved to the provincial level and is, therefore, largely in the hands of local authorities, with the

\footnotetext{
6 In French: "finages"
} 
allocation and signature rights vested in the governor. This situation is expected to lead to healthy competition between the provinces in the granting of these concessions. But it can be also be an obstacle for their allocation if the local government is unfavourable to such an evolution, or is favouring other land-use vested interests.

\section{CONCESSIONS WITH EXCESSIVE AREAS?}

Large forest concessions reserved for local communities exist in Latin America, but the institutional arrangements and, consequently, the collective action, apparently, are not the same throughout the world. Robinson et al. (2011) conducted a meta-analysis of the "forest outcomes" of land tenure arrangements, and noticed contrasting results between Central America (with, globally, rather positive outcomes), South America (mitigated results) and Africa. They especially noticed an "association between negative forest outcomes and communal land in Africa". This suggests that tenure is only one factor among many others (local traditions and history, way of life, economic systems, governance context, etc.) that shapes the outcome of a given tenure system, a point too often overlooked.

Article 18 of the DRC decree stipulates that the size of the concession is to be determined by the local community, based on the traditional land practices (not limited by area), with a ceiling of 50,000 ha. This maximum size may appear huge, since neighbouring countries such as Cameroon, limit community forests to a maximum of 5,000 ha.

There are probably contradictory views on the consequences of granting such large concession areas. One consideration pertains to wildlife management, which, in the neighbouring countries, had become almost irrelevant with the small-size surfaces allowed (because of the need for hunting and the home ranges of the main species). The concept of ecotourism is mentioned in Article 20 of the decree, and the concept of nature conservation in article 65 of order 025 , opening the possibility to concessions managed for nonconsumptive use, such as observation (non-hunting) safaris, ecotourism excursions, and others.

In addition to conservation, the decree provides for artisanal exploitation exclusively in these community concessions, i.e., it expressly precludes industrial operators. However, it is doubtful the communities will have the capacity for the self-management and monitoring of an area as large as 50,000 hectares. In the DRC, the central and provincial governments have a limited ability to control what occurs in areas far away from the large urban centres; this brings up the question of how such large areas would and should be managed. Three illegal channels of amassing wealth could arise quickly, namely:

- The proliferation of contracts with artisanal operators (even if the Ministry Order 025 tries to organise this kind of exploitation) without the possibility of exercising control over their activities. In fact, this aspect relates to both a source of degradation of the forest ecosystem and an informal sector struggling to secure the appropriate licenses for its activities (Lescuyer et al. 2014). Therefore, the risk that these actors, including some (similar to some industrial players) who might have predatory intentions, could become involved in local community concessions has to be taken into account and, if possible, managed;

- Illegal subcontracts with industrial operators (despite the fact that Ministry Order 025 prohibits it), who could exploit the community concessions, without any control being possible.

- Illegal charcoal exploitation, (despite the fact that Ministry Order 025 tries to organise this kind of exploitation).

Obviously, these risks exist regardless of the size of the concessions granted to the communities, but they increase along with the size of the areas involved. This factor could constitute an additional obstacle in verifying the volume of legal timber, i.e., that respects the Forest Law Enforcement, Governance and Trade (FLEGT) process.

\section{CONCESSION OF LOCAL COMMUNITIES AND THE FLEGT PROCESS}

In a global context, where the environment is of main concern, the European Union (EU) has launched the FLEGT programme for timber and timber products ${ }^{7}$. This action plan was published in 2003 as the EU's response to illegal logging (European Commission and Cameroon 2010), which causes significant environmental and social damage. The FLEGT programme includes various measures, including the promotion of the legal timber trade by developing Voluntary Partnership Agreements (VPAs), as well as bilateral agreements between the producing countries and the EU (EU 2007).

The DRC is currently negotiating a VPA. In practical terms, this will involve updating the legislative framework, implementing a legality verification system, and establishing the traceability of wood at a national scale. As these innovations have significant consequences for the local players, they would have to adapt to the process and master new skills. In this agreement, the community concessions could be included in the form of a forest permit, similar to what has been done in Cameroon regarding self-managed community forests. This would ensure the legality of the community timber production, but verification operations could be difficult to perform if the size of community concessions outstrips the local capacity of control.

Many field observations in countries more advanced in the FLEGT process have indicated that there is still a long way to get the first results. A study (Julve et al. 2013) has tested the

\footnotetext{
7 This programme is designated generally by the acronym FLEGT, short for Forest Law Enforcement, Governance and Trade.
} 
FLEGT "legality grid" that the Cameroonian community forests will be obliged to follow soon. The grid was tested on half of the active community forests in Cameroon to analyse the gaps between the activities carried out on the land and the legality indicators included in the grid. The results show that none of the sampled forests fully complied with the requirements of the grid. This study has helped to identify the bottlenecks associated with the complex procedures, the excessive costs imposed by the current regulations, and the lack of electricity and computer facilities in the villages. The future concession-holding communities of the DRC would undoubtedly have to contend with similar bottlenecks.

It is likely that the DRC community concession holders would sell their products principally to the domestic market. In fact, the traceability and verification requirements, essential for issuing the FLEGT licenses required for exporting to the EU, appear to be beyond their technical and financial capacity. Moreover, the DRC government seems unable to provide the concession holders with the necessary assistance. Therefore, it would undoubtedly be more appropriate for the DRC to omit this category of community concessions, especially over large areas, from the scope of the VPA-FLEGT. By so doing, these concessions would not constitute a potential blocking factor for future FLEGT licenses applied for by the industrial exporters. In any case, the DRC government should be obliged to decriminalise artisanal logging, i.e., adapt the legal and fiscal framework to the constraints facing these economic agents, and introduce a process that would facilitate the regulation of this subsector.

\section{CONCLUSION}

Although progress on the legal front has not yet led to the implementation of the recommended process, the promulgation of Decree 14/018 and Ministerial Order 025 on forest concessions for local communities was undoubtedly a positive development for social forestry in the DRC. Rainforest Foundation (2016) estimated that 75 million hectares could be allocated in concessions for communities in DRC. This creates a considerable challenge for local populations. The explicit recognition of the distinction between a customary de facto local community forest and a modern legal entity (concession), based on customary practices, is genuinely innovative. This aspect distinguishes the DRC decree from the decrees governing "one-dimensional" community forestry in the other countries of the sub-region. The emphasis on joint ownership of the concession for the benefit of the entire community (not for an association) aims to avert the risk of privatisation by the members of the association. Moreover, the proposed governance structures are intended to avert the risk of seizure by the elites. However, viewed from the perspective of the long-established customs and traditions, the question remains whether these measures would be sufficient.
Other interesting factors appear in the decree, such as participatory demarcation, the decentralised character, and possible forms of social forestry oriented toward non-timber valorisation methods, such as remunerated conservation, and ecotourism. Selecting a maximum area of 50,000 ha for the community concessions, in contrast to the 10,000 ha proposed in the preliminary draft, undoubtedly demonstrated a shift in the government policy away from the industrial timber exploitation model. This can be related with the fact that industrial forestry has been opposed by some of the environmentalist NGOs and has been blamed repeatedly for its poor contribution to the GDP of the DRC. Many uncertainties remain, however, pertaining to the participation of migrants and women, as well as to the potential for degradation related to artisanal operations, the unsustainable nature of which in the DRC has been demonstrated again recently (Mégevand 2013). Another reservation is related to illegal industrial operations that could possibly benefit from areas that are too large to be effectively controlled.

Finally, a 2015 Order (no. 050 of 23 September 2015) raised strong concerns among the advocates of community forestry in DRC. This order establishes artisanal concessions "in favour of local communities" but to be held and managed by the "Decentralised Territorial Entities" (ETDs, the French acronym) on the basis of an agreement with local communities with customary land rights to the area. These new concessions would have a maximum area of 500 ha (without mention of the maximum volume of timber to be extracted) and timber exploitation could be outsourced. This order is seen as creating unfair competition with the potential community concessions, since the local governments, which could derive financial benefits from these artisanal concessions would have the decision-making authority. ETDs encompass local councils, but also chieftaincies and other entities, which are recognized as having a legal personality, unlike the communities (which have to set up an association or a cooperative to exploit the community concession). The argument about the legal personality is put forward by the advocates of this order. It expresses the rampant opposition of those within the Ministry in charge of the forests who are opposed to community forestry, as they do not believe in the communities' capacity for sustainable forest management. This shows that there is still a long way to go before this community forestry model can be implemented in the DRC, in spite of (successful) efforts to pass innovative regulations.

\section{ACKNOWELDGEMENT}

Cédric Vermeulen thanks COFORTIPS Project founded by ERA-Net BiodivERsA with ANR (France), BELSPO (Belgium) and FWF (Austria). The valuable suggestions made by anonymous referees are grateful acknowledged.

\footnotetext{
8 "Most VPAs include a table, called a legality grid or legality matrix, to present the definition of legality. The tables outline the legal requirements, usually called 'indicators', which make up the legality definition. The tables also describe the means by which a national authority will verify legality" (http://www.euflegt.efi.int/legality-definition)
} 


\section{REFERENCES}

BOLDRINI, S., MEUNIER, Q., GILLET, P., ANGONE, R. and VERMEULEN, C. 2014. The role of the youth in community forestry in Gabon. Nature et Faune 28(1): $56-59$.

BOUKI, T. 2016. La participation dans les forêts communautaires du Sud Cameroun. In La gestion inclusive des forêts d'Afrique centrale. Passer de la participation au partage des pouvoirs, Buttoud \& Nguinguiri eds, FAO, CIFOR, pp 47-61.

BRAY, D.B., E. DURAN, V.H. RAMOS, J.-F. MAS, A. VELAZQUEZ, R.B. MCNAB, D. Barry, and RADACHOWSKY J. 2008. Tropical deforestation, community forests, and protected areas in the Maya Forest. Ecology and Society 13(2): 56

DEBROUX, L., HART, T., KAIMOWITZ, D., KARSENTY, A. and TOPA, G. 2007. Forests in post-conflict Democratic Republic of Congo, Analysis of a Priority Agenda. World Bank, Cirad, Cifor, Bogor, 82 p.

DEFOURNY, P. DELHAGE, C. and KIBAMBE J.-P. 2011. Analyse quantitative des causes de la déforestation et de la dégradation des forêts en République Démocratique du Congo UCL/FAO/National REDD Coordination, 105 p.

EU (European Union), 2007. FLEGT. Informative note 1.

EZZINE de BLAS, D., RUIZ PEREZ, M. and VERMEULEN, C. 2011. Management conflicts in Cameroonian community forests. Ecology and Society 16(1).

EUROPEAN COMMISSION and CAMEROON. 2010. FLEGT Voluntary Partnership Agreement between Cameroon and the European Union. Yaoundé.

GILLET P., VERMEULEN, C., FEINTRENIE, L. DESSARD, H. and GARCIA, C. 2016. Quelles sont les causes de la déforestation dans le bassin du Congo? Synthèse bibliographique et études de cas. Biotecnol. Agron. Soc. Environ.

JULVE, C., ECKEBIL, T.P., NZOYEM SAHA, N., TCHANTCHOUANG, J.-C., KERKOHF, B., BEAUQUIN, A., MBARGA MBARGA, J.-P., VERMEULEN, C., CERRUTI, P.O. and LESCUYER, G. 2013. Forêts communautaires camerounaises et Plan d'action 'Forest Law Enforcement, Governance and Trade' (FLEGT): quel prix pour la légalité? Bois et Forêts des Tropiques 317(3): 71-80.

JULVE, C., VANDENHAUTE, M., VERMEULEN, C., CASTADOT, B., EKODECK, H. and DELVINGT, W. 2007. Séduisante théorie, douloureuse pratique: la foresterie communautaire camerounaise en butte à sa propre législation. Parcs et Réserves 62(2): 18-24.

KARSENTY, A. and VERMEULEN, C. 2016. Toward "Concessions 2.0": articulating inclusive and exclusive management in production forests in Central Africa. International Forestry Review 18(S1).
LAURENT, P.J. and MATHIEU, P. 1994. Migration, environnement et projet de développement: récit d'un conflit foncier entre Nuni et Mossi au Burkina Faso". Cahiers du Ciped 20 (Migrations et accès à la terre au Burkina Faso, LAURENT, MATHIEU and TOTTE, eds.): 87-129.

LEE, J. and HUBERT, H. 2015. Établir le contexte: vue d'ensemble de l'état du secteur forestier en RDC. In: $L a$ gestion d'une ressource précieuse: Des notes politiques pour améliorer la durabilité la production forestière de la RDC, Groupe de la Banque Mondiale, Internal Report, $76 \mathrm{p}$.

LESCUYER, G., BOUTINOT, L., CERUTTI, P. and TSANGA, R. 2015. Note de politique 2: Foresterie communautaire. In: La gestion d'une ressource précieuse: Des notes politiques pour améliorer la durabilité la production forestière de la $R D C$, Groupe de la Banque Mondiale, Internal report, $76 \mathrm{p}$.

LESCUYER, G., CERUTTI, P.O., TSHIMPANGA, P., BILOKO, F., ADEBU-ABDALA, B., TSANGA, R., YEMBE-YEMBE, R.I. and ESSIANE-MENDOULA, E. 2014. Le marché domestique du sciage artisanal en République démocratique du Congo. État des lieux, opportunités, défis. Bogor, Indonesia: CIFOR (Occasional Paper 110).

MEGEVAND, C. 2013. Dynamiques de déforestation dans le bassin du Congo: réconcilier la croissance économique et la protection de la forêt. Washington, DC: World Bank, $180 \mathrm{p}$.

RAINFOREST FOUNDATION, 2016. Note sur les forêts communautaires en RDC. Vers une gestion équitable et durable des forêts. Rainforest Foundation, London, 10 p.

ROBINSON, B.E., HOLLAND, M.B. and NAUGHTONTREVES, L. 2011. Does secure land tenure save forests? A review of the relationship between land tenure and tropical deforestation. CCAFS Working Paper 7. CGIAR, Copenhagen.

SCHIPPERS, C., DOUCET, J.-L., BRACKE, C., BOLDRINI, S. and VERMEULEN, C. 2008. Une forêt communautaire n'est pas une concession: adapter les plans simples de gestion. In C., Vermeulen, C. and J.-L., Doucet (Eds.), Les premières forêts communautaires du Gabon: Récits d'une expérience pilote. Sainte-Ode, Belgique: 69-80 pp.

TOBITH, C. and CUNY, P. 2006. Genre et foresterie communautaire au Cameroun. Quelles perspectives pour les femmes? Bois et Forêts des tropiques 289(3): 17-26.

VERMEULEN, C., VANDENHAUTE, M., DETHIER, M., EKODECK, H., NGUENANG, G.-M. and DELVINGT, W. 2006. De Kompia à Djolempoum: sur les sentiers tortueux de l'aménagement et de l'exploitation des forêts communautaires au Cameroun. Vertigo 7(1): 1-8.

VUNDU DIA MASSAMBA, V. and KALAMBAY LUMPUNGU, G. 2013. Code Forestier commenté et annoté. Act no. 11/2002 of 29 August 2002. Kinshasa: DRC, IUCN, USAID. 